\title{
Synthetic lethality: the road to novel therapies for breast cancer
}

\author{
Kiranjit K Dhillon 1,*, Ilirjana Bajrami2,*, Toshiyasu Taniguchi' and Christopher J Lord² \\ 'Fred Hutchinson Cancer Research Center, Seattle, Washington, USA \\ 2The CRUK Gene Function Laboratory and Breast Cancer Now Toby Robins Research Centre, \\ The Institute of Cancer Research, London, UK \\ *(K K Dhillon and I Bajrami contributed equally to this work)
}

Correspondence

should be addressed

to C J Lord or T Taniguchi

Email

chris.lord@icr.ac.uk or

ttaniguc@fredhutch.org

\begin{abstract}
When the BRCA1 and BRCA2 tumour suppressor genes were identified in the early 1990s, the immediate implications of mapping, cloning and delineating the sequence of these genes were that individuals in families with a BRCA gene mutation could be tested for the presence of a mutation and their risk of developing cancer could be predicted. Over time though, the discovery of $B R C A 1$ and $B R C A 2$ has had a much greater influence than many might have imagined. In this review, we discuss how the discovery of $B R C A 1$ and $B R C A 2$ has not only provided an understanding of the molecular processes that drive tumourigenesis but also reignited an interest in therapeutically exploiting loss-offunction alterations in tumour suppressor genes.
\end{abstract} Key Words

- bRCA1

- bRCA2

- breast

\section{BRCA1 and BRCA2: discovery, genetics and biology}

Globally, breast cancer is the most common cancer in women. Its familial form constitutes $5-10 \%$ of all breast cancers and has a dominant mode of inheritance and is characterised by earlier onset of disease, relative to breast cancer in the general population. Heterozygous germline mutations in either the BRCA1 or BRCA2 tumour suppressor genes are the most common genetic cause of familial breast cancer and were identified as breast cancer susceptibility genes in the 1990s through linkage analysis in families with the disease (Futreal et al. 1994, Miki et al. 1994, Wooster et al. 1995, Tavtigian et al. 1996, King 2014). BRCA1 and BRCA2 mutations are found in $25-28 \%$ of familial breast cancers, and mutation carriers have a lifetime risk of $40-87 \%$ for developing breast cancer by the age of 70 years. Mutation carriers also have a lifetime risk of $45-60 \%$ (BRCA1 mutation carriers) or 11-35\% (BRCA2 mutation carriers) for developing ovarian cancer (Ford et al. 1998, King et al. 2003). Other types of cancers also found in BRCA1 and BRCA2 mutation carriers include pancreatic and prostate cancers (Ozcelik et al. 1997, Breast Cancer Linkage Consortium 1999, Antoniou et al. 2003, Edwards et al. 2003, King et al. 2003, van Asperen et al. 2005). Although most familial $B R C A 1$ or BRCA2 mutations are inherited as heterozygous mutations, rare, biallelic germ-line mutations do occur in patients with Fanconi anaemia (Howlett et al. 2002, Domchek et al. 2013, Meyer et al. 2014, Sawyer et al. 2015). Furthermore, in addition to germ-line mutations in these genes, somatic BRCA1 and BRCA2 mutations are also found in breast, prostate, ovarian and pancreatic cancers, as is somatic hypermethylation of the BRCA1 gene promoter. An analysis of tumours from individuals with BRCA1 or BRCA2 mutations indicates that the wild-type allele is generally lost (Futreal et al. 1994,

This paper forms part of a thematic review section on 20 Years of BRCA 1 and 2 The Guest Editors for this section were Kokichi Sugano and William Foulkes 
Collins et al. 1995, Gudmundsson et al. 1995), suggesting that loss of heterozygosity at the BRCA1 and BRCA2 loci appears to be an important event for tumourigenesis.

Both BRCA1 and BRCA2 are relatively large genes, which display limited sequence homology to each other. $B R C A 1$ comprises 24 exons that translate to a 1863 amino acid protein with a RING domain with E3 ubiquitin ligase activity, a coiled-coil domain in the largely unstructured central region important for binding with another tumour suppressor protein, PALB2, and BRCT (BRCA1 carboxy terminal) repeats important for interaction with phosphorylated proteins (Wu et al. 1996, Brzovic et al. 2001, Xia et al. 2006, Sy et al. 2009, Zhang et al. 2009b). BRCA2 comprises 27 exons that translate to a 3418 amino acid protein that includes amino-terminal BRC repeats, which mediate binding of BRCA2 to PALB2 and the DNA recombinase RAD51, a central DNA binding domain, and nuclear localisation and RAD51 control domains at the carboxy-terminus (Sharan et al. 1997, Wong et al. 1997, Yang et al. 2002).

Small insertions/deletions (in-dels) or nonsense mutations leading to truncations are the most common $B R C A$ gene mutation types observed in cancer patients. At least 1790 distinct mutations, polymorphisms and variants have been identified in BRCA1 to date and over 2000 of them have been identified in $B R C A 2$ according to the Breast Cancer information Core (BIC) and ClinGen. Mutations are distributed across the entire coding sequence for both genes with over $50 \%$ of observed mutations being unique to particular individuals. In addition to known pathogenic mutations, there are a large number of missense, in-frame deletion and silent mutations known as 'variants of unknown significance', which have unclear pathogenic potential, making clinical interpretation of genetic testing difficult in cancer patients harbouring these variants.

Breast tumours in BRCA1 mutation carriers tend to have a basal-like transcriptional signature and more often than not exhibit a 'triple-negative' phenotype, lacking expression of the oestrogen and progesterone receptors and lacking amplification of the ERBB2 (HER2) oncogene (Foulkes et al. 2003). This triple-negative phenotype precludes the use of targeted oestrogen receptor-based or ERBB2-specific therapies, and in general, BRCA1 mutant breast cancers are treated with traditional genotoxic chemotherapy agents. In contrast, breast tumours in BRCA2 mutation carriers tend to better reflect the hormone receptor and ERBB2 status of breast cancers in the non-BRCA mutant population (Jonsson et al. 2010, Waddell et al. 2010).

\section{BRCA1 and BRCA2 functions in DNA repair and replication fork protection}

Tumourigenesis occurs in the absence of BRCA1 and BRCA2 as both proteins play important roles in the repair of DNA double-strand breaks (DSBs) (Moynahan \& Jasin 2010) and the stability of replication forks. DSBs, the most toxic type of DNA lesions, can be catastrophic for the cell if left unrepaired as they compromise the double helix structure of DNA. The two main methods of DSB repair are the error-prone non-homologous end-joining (NHEJ) pathway and the error-free homologous recombination (HR) pathway. NHEJ, used predominantly in the $G_{1}$ phase of the cell cycle, can result in loss of genetic information proximal to the DSB site. In contrast, HR, active during $\mathrm{S}$ and $G_{2}$ phases, uses homologous sequence from a sister chromatid for error-free repair of DSBs. In HR, after the initial detection of the DSB, the broken DNA ends are enzymatically resected to generate 3 ' single-stranded DNA (ssDNA). The ssDNA is coated by the replication protein A (RPA) complex, which is then replaced by the RAD51 recombinase. The binding of multiple RAD51 molecules onto ssDNA enables strand invasion, in which ssDNA from the damaged DNA site invades the double helix of intact DNA, a process that facilitates the identification of a homologous DNA sequence that is used as a template for DNA repair across the break site. Efficient resolution of the resulting intermediates completes the process, and the genetic integrity of broken DNA is restored.

BRCA1 and BRCA2 play key roles in HR. BRCA1 is required for CtIP-mediated resection of DSBs to generate single-stranded DNA (ssDNA), which is coated by the RPA complex (Yu \& Baer 2000, Chen et al. 2008). BRCA1mediated resection is a key step in committing to repair by HR as opposed to the error-prone NHEJ pathway (Kass \& Jasin 2010). CDK-phosphorylated CtIP protein binds BRCA1 BRCT repeats, is localised to the DSB and mediates resection through the MRN (MRE11-RAD50-NBS1) complex (Wong et al. 1998, Yu et al. 1998, Sartori et al. 2007, Chen et al. 2008). In addition to CtIP localisation to DSBs, BRCA1 also counteracts 53BP1 function, and in doing so impairs NHEJ (Bouwman et al. 2010, Bunting et al. 2010). Additionally, both BRCA1 and BRCA2, bridged by PALB2, are required for the recruitment of the DNA recombinase RAD51 to damaged DNA, where it forms a nucleoprotein complex (or 'filament') with ssDNA that mediates strand invasion (Xia et al. 2006, Sy et al. 2009, Zhang et al. $2009 a, b$, Tischkowitz \& Xia 2010). BRCA2 is not only required for localisation of RAD51 to RPA-coated DNA

Published by Bioscientifica Ltc 
A

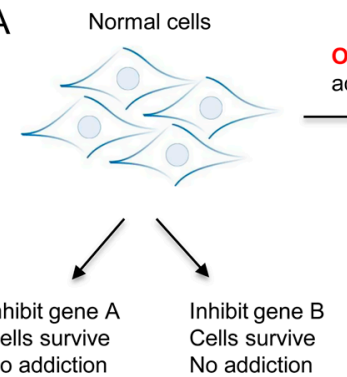

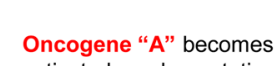
activated e.g. by mutation
Tumour cells with activated Oncogene A
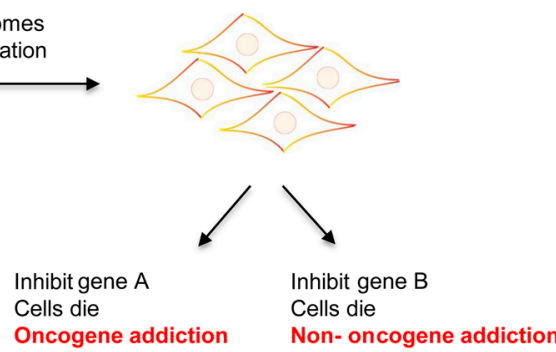

B
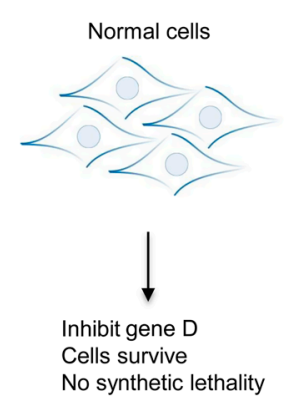

Tumour suppressor "C" becomes inactivated e.g. by mutation but also for stabilising the RAD51 nucleofilament that is formed by blocking RAD51-mediated ATP hydrolysis.

When the progression of replication forks is halted (replication fork stalling), which can be caused by a variety of factors including damaged DNA lesions being encountered by the replication fork or the relative absence of the requisite nucleotides, preventing the disintegration or collapse of the fork structure is key to the continued fitness of cells. One of the molecular events that challenges fork stability in this setting is the activity of the nuclease MRE11, which if not tightly controlled degrades the newly synthesised (nascent) DNA at the replication fork, potentially forcing fork collapse. In addition to their roles in DSB repair, BRCA1 and BRCA2 prevent the degradation of nascent DNA at stalled replication forks (Schlacher et al. 2011, Schlacher et al. 2012, Pathania et al. 2014). For example, Schlacher and coworkers found using single-molecule DNA fibre analysis that once replication forks are stalled with hydroxyurea (HU), tracts of nascent DNA produced before fork stalling are degraded in the absence of BRCA2 by MRE11. This protection of nascent DNA at replication forks appears to be mediated by a conserved C-terminal region in BRCA2 that stabilises RAD51 nucleoprotein filaments but is not required for RAD51 loading or homologous recombination per se (Schlacher et al. 2011). Using Brca1-deficient embryonic stem (ES) cells, Schlacher and coworkers later found that Brca1 also prevents fork degradation by MRE11 (Schlacher et al. 2012).
The loss of DNA repair and fork stability functions of BRCA1 and BRCA2 is the likely cause of the genomic instability seen in BRCA1 or BRCA2 mutant tumours. Cells deficient in either protein have been shown to have reduced efficiency of HR (Moynahan et al. 2001a,b). BRCA1/2deficient cells also exhibit spontaneous and DNA damageinduced genetic instability, which subsequently contributes to tumourigenesis. Additionally, BRCA1/2-deficient cells are sensitive to DNA-damaging agents, especially those that form crosslinks on DNA such as cisplatin (Narod 2010). This particular phenotype has been exploited in the clinic to treat BRCA-deficient tumours. In fact, cisplatin and its derivative, carboplatin, have been shown to be particularly effective in the treatment of BRCA1- and BRCA2associated cancers, particularly in ovarian cancers (Boyd et al. 2000, Cass et al. 2003, Chetrit et al. 2008, Tan et al. 2008, Vencken et al. 2011). However, chemoresistance to platinum compounds is a very significant clinical problem and has a negative impact on patient survival. Therefore, identification of additional drugs that can effectively treat HR-deficient cancers by exploiting synthetic lethal gene interactions is essential (Fig. 1).

\section{Therapeutic exploitation of BRCA gene defects with PARP inhibitors}

The intricate dissection of BRCA1 and BRCA2 function, and in particular the discovery that these tumour suppressor proteins were required for effective HR, 
made a significant impact on the discovery and mechanistic understanding of therapeutic approaches that target BRCA1 or BRCA2 (BRCA1/2) gene mutant cancers. To date, most agents proposed to selectively inhibit BRCA1/2 mutant tumour cells likely do so by causing the stalling and collapse of DNA replication forks. Specifically, these agents cause replication fork damage that requires HR for repair (Fig. 2). In the absence of BRCA1 or BRCA2 gene function, and therefore functional HR, tumour cells most likely attempt to repair replication forks via non-HR forms of DNA repair. These alternative repair strategies cause large-scale chromosomal abnormalities, which ultimately impair the fitness of cells and induce cell death. Early evidence of this phenomenon was suggested by work illustrating the sensitivity of $B R C A$ gene-defective cells to platinum salts (Fedier et al. 2003, Bartz et al. 2006, Evers et al. 2008) or topoisomerase inhibitors such as camptothecin (Rahden-Staron et al. 2003). Platinum salts most likely stall replication forks by causing intra-strand and inter-strand crosslinks in DNA through covalent interaction with nucleophilic N-7 sites on purine residues (Sikov 2015). These 'lesions' within the DNA structure prevent normal unwinding of the DNA double helix before replication (Fig. 2, Sikov 2015). DNA topoisomerase enzymes bind DNA and unwind its helical structure (Champoux 2001), a prerequisite for multiple processes such as DNA replication, transcription, recombination and chromatin remodelling (Champoux 2001). Topoisomerase inhibitors (also known as topopoisons) such as camptothecin fix or 'trap' topoisomerase on DNA (O'Connell et al. 2010, Lord \& Ashworth 2012). Presumably, this trapped form of topoisomerase provides a bulky structure, which prevents the progression of the replication fork (Fig. 2, O'Connell et al. 2010).

At least in in vitro tissue culture models, platinum salts and topoisomerase inhibitors selectively target BRCA1/2 gene mutant tumour cells, compared with cells with 'wild-type' function, but still have relatively profound inhibitory effects on wild-type cells (Evers et al. 2008). Conversely, work from two teams in 2005 suggested that small molecule inhibitors of the DNA repair enzyme poly (ADP-ribose) polymerase (PARP) - caused profound cell inhibitory effects in BRCA1 (Farmer et al. 2005) or BRCA2 mutant (Bryant et al. 2005, Farmer et al. 2005)

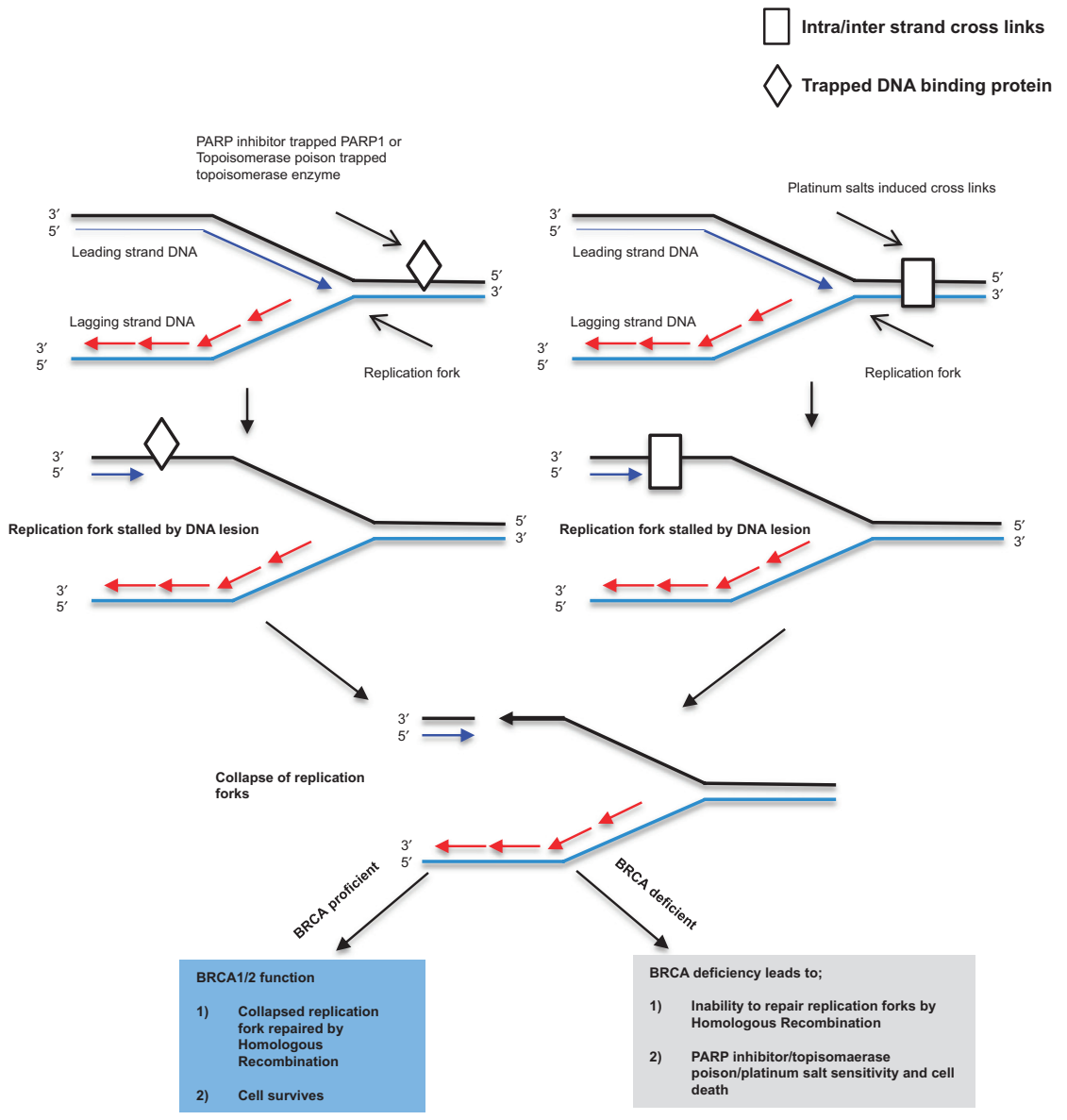

Figure 2

DNA lesions causing replication fork collapse. A working model of the DNA damage response (DDR) to replication fork stalling agents is shown. Drug-like PARP inhibitors trap PARP on DNA. Likewise, topoisomerase poisons trap topoisomerase enzymes on DNA. Platinum salts cause DNA crosslinks. Each of these events stalls the progression of replication forks in $\mathrm{S}$ phase. Stalled forks often collapse, forming doublestrand DNA breaks. DSBs in this setting are often cytotoxic if not repaired. The normal DNA repair process, homologous recombination, is controlled by BRCA1 and BRCA2. BRCA1 function is required for the processing of DNA ends before repair, a process known as end resection. Once end resection is complete, BRCA2 localises the key DNA recombinase enzyme, RAD51, to DNA at the site of DNA damage. The binding of RAD51 to DNA allows damaged DNA to invade an intact DNA double helix with homologous DNA sequence to that at the site of DNA damage (often in the sister chromatid), which is used as a template on which new DNA could be synthesised as part of the DNA repair process. In the absence of functional BRCA1 and BRCA2, cells either fail to effectively repair DNA (which can lead to apoptosis) or to use orthogonal DNA repair processes such as non-homologous end joining, which increase the frequency of complex DNA rearrangements, events that ultimately impair the fitness of cells. 
tumour cells but had minimal effects in wild-type cells with functional HR. PARP1 is an enzyme that uses $\beta$-NAD+ as a co-factor to synthesise poly(ADP-ribose) chains (PAR) on target proteins and has a known role in the repair of single-strand DNA breaks (breaks in one strand of the DNA double helix) (Hottiger et al. 2010). At the time, it was thought that the inhibition of PARP activity might cause an accumulation of DNA damage that requires HR for its repair (Bryant et al. 2005, Farmer et al. 2005). Subsequently, this hypothesis has been refined by data suggesting that the key cytotoxic DNA lesion in PARP inhibitor-exposed tumour cells is PARP 'trapped' on DNA (Fig. 2, Murai et al. 2012 , 2014), a mechanism reminiscent of that used to explain the BRCA selectivity of topoisomerase inhibitors. PARP binds damaged DNA and then initiates a series of PARylation events. One of these events is autoPARylation (PARylation of PARP itself), which causes the release of PARP once its role in the initial phase of DNA repair is complete (Murai et al. 2012). It seems possible that some catalytic inhibitors of PARP impair autoPARylation, thus trapping PARP on the double helix, where it is able to stall and collapse replication forks (Fig. 2).

A number of years after the pre-clinical observation of PARP inhibitor/BRCA gene synthetic lethality, clinical trials, including those which studied breast cancer patients, confirmed the potential of PARP inhibitors as treatments for $B R C A$ gene mutant cancers. Although these trials have recently been reviewed in detail elsewhere (Balmana et al. 2011, Livraghi \& Garber 2015, Lord et al. 2015), the key trials can be summarised as follows:

\section{Early phase 1 trials show sustained anti-tumour responses in germ-line BRCA mutant cancers}

Although the first-in-human PARP inhibitor clinical trial assessed the safety of rucaparib (Pfizer), olaparib (aka AZD2281, Lynparza, KuDOS/AZ) was the first PARP inhibitor to be formally assessed in $B R C A 1 / 2$ gene mutant patients. In a phase 1 clinical trial of olaparib (Fong et al. 2009), 60 patients were treated with $400 \mathrm{mg}$ twice daily olaparib, 19 of whom had germ-line mutations in either $B R C A 1$ or $B R C A 2$. In this subset of BRCA1/2 gene mutant patients, 63\% exhibited a clinical benefit from olaparib treatment, as defined by radiological and/or tumour marker responses or disease stabilisation for a period greater than 4 months (Fong et al. 2009). Even though dose-limiting myelosuppression and central nervous system side effects were seen in some patients, many of the sustained anti-tumour responses were not associated with the deleterious side-effect profile normally associated with classical chemotherapy (Fong et al. 2009). Based on these promising results, the same phase I trial was subsequently expanded to include a total of 50 germ-line $B R C A 1 / 2$ mutant carriers with ovarian, primary peritoneal or fallopian tube carcinoma. Here, an overall response rate (ORR) of $40 \%$ and a disease control rate (DCR) of $46 \%$ were observed (Fong et al. 2010). In a retrospective analysis of this study, a significant correlation between a good response to prior platinum salt treatment and subsequent therapeutic response to olaparib was seen (Fong et al. 2010). One explanation for this correlation is that both platinum salts and PARP inhibitors stall replication forks and require HR for the repair of the subsequent DNA lesions caused (Fig. 2).

\section{Key phase 2 clinical trials in germ-line or somatic BRCA mutated cancers}

The promising results from this phase I clinical study prompted two phase 2 clinical trials investigating singleagent olaparib in patients with BRCA gene mutant chemotherapy-resistant breast (Tutt et al. 2010) or ovarian cancers (Audeh et al. 2010). These trials, which used either a $400 \mathrm{mg}$ or $100 \mathrm{mg}$ twice-daily treatment regimen, established an ORR of 33\% in ovarian cancer patients in the $400 \mathrm{mg}$ twice-daily treatment schedule and $13 \%$ of the $100 \mathrm{mg}$ twice-daily group, with a median progression-free survival (PFS) of 5.8 months and 1.9 months, respectively (Audeh et al. 2010). Similar response rates were observed in the breast cancer cohort, where a response rate (RR) of $22 \%$ was seen in the $100 \mathrm{mg}$ twice-daily cohort (PFS 3.8 months), whereas a RR of $41 \%$ was observed in the cohort receiving a higher dose of olaparib (PFS 5.7 months) suggesting that the higher dose was essential to achieve a maximal clinical response.

As discussed later, many sporadic ovarian serous and non-familial triple-negative breast cancers display many of the molecular and histopathological features found in germ-line $B R C A 1 / 2$ gene mutant tumours, which are often driven by somatic mutations in BRCA1, BRCA2 and other HR-modifying genes, a concept termed 'BRCAness' (Turner et al. 2004). On this basis, olaparib was also assessed as a monotherapy in sporadic cancers thought to display the BRCAness phenotype, namely high-grade serous ovarian cancer (HGSOvCa) and triplenegative breast cancers (described earlier). In patients with HGSOvCa both BRCA1/2 gene mutant and nonmutant patients demonstrated a number of sustained therapeutic responses to olaparib, a number of which were also associated with prior platinum sensitivity

Published by Bioscientifica Ltd. 
(Gelmon et al. 2011). In triple-negative breast cancer patients, those with $B R C A 1 / 2$ gene mutations exhibited a higher frequency of disease stabilisation in response to olaparib treatment than those without BRCA1/2 gene mutations ( $63 \%$ vs $13 \%)$, but unlike in the ovarian cancer cohort, no sustained responses were achieved in either the BRCA1/2-mutant or non-mutant patients (Gelmon et al. 2011). Alongside these studies, olaparib was assessed as a maintenance therapy (i.e. a therapy used to reduce disease recurrence after chemotherapy) in patients with HGSOvCa who had previously received carboplatin, a platinum salt chemotherapy ((Ledermann et al. 2012) NCT00753545, Study 19). In this study, 136 patients received olaparib after chemotherapy, with 129 receiving a placebo instead. A preliminary analysis of this trial suggested that when used as a maintenance monotherapy, olaparib significantly improved PFS, and time to first and second subsequent therapy or death compared with the use of a placebo in the maintenance setting, with $B R C A 1 / 2$ mutant patients (be it germ-line or somatic) in the trial deriving the greatest benefit from olaparib. However, an effect on OS in either $B R C A 1 / 2$ gene mutant or non$B R C A 1 / 2$ gene mutant patients was not seen (Ledermann et al. 2014). Nevertheless, the improvements in PFS were sufficient to warrant an approval by the FDA and EMA for olaparib as a maintenance monotherapy in HGSOv cancer characterised by BRCA1/2 gene mutation, making this PARP inhibitor not only the first synthetic lethal treatment for cancer to be approved but also the first treatment for an inherited cancer (Kim et al. 2015). A retrospective analysis of data from study 19 , conducted after $77 \%$ of the patients had died, has now shown an overall survival benefit from olaparib maintenance monotherapy. In the BRCA mutant patients, this OS benefit was not only most pronounced (median OS 34.9 months for olaparib vs 30.2 months for placebo, hazard ratio (HR) of 0.62 ) but was also seen in the entire dataset, which included both BRCA1/2 mutant and non-BRCA1/2 mutant patients (OS 29.8 months (olaparib) vs 27.8 (placebo), HR 0.73) (Ledermann et al. 2016).

Additional clinical trials observed responses to olaparib in patients with $B R C A 1 / 2$ mutations in a spectrum of other BRCA1/BRCA2-associated cancers including pancreatic and prostate cancers (Kaufman et al. 2015). Notable among these studies has been the TOPARP phase II clinical trial assessing the efficacy of olaparib in men with metastatic, castration-resistant prostate cancer (Mateo et al. 2015). Of the 49 patients who underwent prior treatment (docetaxel, the androgen synthesis inhibitor abiraterone or the androgen receptor inhibitor enzalutamide) and received oral olaparib at $400 \mathrm{mg}$ twice daily,
14 showed a response to olaparib; seven of these patients harboured BRCA2 defects and four exhibited tumourspecific ATM defects, raising the possibility that other genes involved in HR, such as ATM, might also be good predictive biomarkers of olaparib response (Mateo et al. 2015). On the basis of this study, olaparib has now been given breakthrough status in prostate cancer, and an expansion of the TO-PARP trial to a larger number of patients with HR gene defects is now underway.

Although not all PARP inhibitor trials have delivered such positive results (Lord et al. 2015), the clinical responses in the phase 2 trials described previously, alongside the favourable side-effect profile of PARP inhibitors, such as olaparib, talazoparib, rucaparib, niraparib and veliparib, have provided the impetus for initiating a series of phase III trials, including those in breast cancers. It is expected that within a few years, the data from these trials will provide some of the definitive information that could support or refute the case for using PARP inhibitors in cancers other than HGSOv cancer.

\section{Additional BRCA-directed therapy}

As described previously, in addition to PARP inhibitors, a number of conventional chemotherapies routinely used in the management of cancer might also provide an approach to target $B R C A 1 / 2$ mutant tumours. These include not only platinum agents, topoisomerase I inhibitors (topotecan and camptothecin) and topoisomerase II inhibitors (doxorubicin and etoposide) described previously but also nucleoside analogous such as gemcitabine, which prevents DNA synthesis when incorporated into DNA by preventing chain elongation during DNA replication (Gandhi et al. 1996, Lord \& Ashworth 2016). The common mechanism of action of these agents is that they can stall the normal progression of replication forks and likely require $B R C A$ and $\mathrm{HR}$ function for the repair of the DNA lesions they cause. These agents have been assessed both pre-clinically (Fedier et al. 2003, Rahden-Staron et al. 2003, Bartz et al. 2006) and clinically and have shown selectivity in BRCA1/2-defective backgrounds (Kilburn \& Group 2008, Silver et al. 2010).

One of characteristics of $B R C A 1 / 2$ mutant tumours is an elevated mutational load, compared with non-BRCA1/2 mutant tumours, a likely effect of defective HR. Clinical responses to immune checkpoint inhibitors such as anti-PD-1 and anti-PD-L1 antibodies have previously been associated with hypermutated cancers, including lung carcinomas and melanomas. It seems possible that similar approaches could be used to target BRCA mutant tumours.

Published by Bioscientifica Ltd. 
To investigate this, Strickland and coworkers recently predicted neoantigen load in BRCA1/2-mutated HGSOv tumours and found that this was elevated compared with tumours without HR gene defects, as were the presence of CD3+ and CD8+ tumour-infiltrating lymphocytes and PD-1 and PD-L1 expression in tumour-associated immune cells (Strickland et al. 2016). Such an analysis therefore supports the clinical assessment of combinations of PARP inhibitors with PD-L1 inhibitors in breast and ovarian cancers (e.g. NCT02484404 (Lee et al. 2016)), as do data from a pre-clinical study illustrating the efficacy of an antiCTLA4 antibody in combination with the PARP inhibitor veliparib in a mouse model carrying a Brca1 mutant tumour (Higuchi et al. 2015).

\section{Drug resistance in a BRCA mutant setting}

Although PARP inhibitors have shown to be useful for the treatment of BRCA1/2-associated cancers, PARP inhibitor resistance is likely to be a major obstacle to the overall effectiveness of treatment (Fong et al. 2009, Tutt et al. 2010). PARP inhibitor resistance, in BRCA1 or BRCA2 mutant cancers, can occur due to the reversal of synthetic lethality by several mechanisms including restoration of DSB repair by HR, loss of PARP1 expression, loss of 53BP1 expression and upregulation of PARP inhibitor efflux from cells (Fig. 3).

\section{Restoration of BRCA1/2 function as a mechanism of PARP inhibitor resistance}

We and others hypothesized that restoration of $\mathrm{HR}$ may be able to reverse chemosensitivity to DNAdamaging drugs in BRCA1/2-deficient cells based on the observation that spontaneously occurring secondary genetic alterations could compensate for the initial disease-causing mutations in some patients with Fanconi anaemia (FA), including reversal of DNA damaging agent sensitivity in cells (Hirschhorn 2003, Ikeda et al. 2003, Wiegant et al. 2006). We hypothesized that acquired secondary intragenic $B R C A 1$ or $B R C A 2$ mutations may reverse the effect of the initial disease-causing $B R C A 1 / 2$ mutations in tumours and result in resistance to PARP inhibitors and DNA crosslinking drugs such as cisplatin and carboplatin (Edwards et al. 2008, Sakai et al. 2008, 2009, Swisher et al. 2008).

Evidence for secondary BRCA1/2 mutations as a method of reversing PARP inhibitor-related synthetic lethality was first demonstrated in several in vitro and in vivo drug-selected BRCA2 mutated cell lines (Edwards et al. 2008, Sakai et al. 2008, 2009). PARP inhibitor- or cisplatin-selected clones of the pancreatic cancer cell line CAPAN-1 (BRCA2.6147delT) and ovarian cancer cell line PEO1 (BRCA2.5193C>G) acquired secondary BRCA2 mutations that restore the open reading frame and express functional BRCA2 protein (Edwards et al. 2008, Sakai et al. 2008, 2009). PARP inhibitor-resistant clones had internal insertions or deletions in the $B R C A 2$ gene that eliminated the truncating effect of the parental c.6147delT mutation in CAPAN-1 cells and changed the nonsense mutation in PEO1 cells to a missense mutation. PEO4 ovarian cancer cells derived from the same patient as PEO1 cells, after the onset of clinical resistance, were resistant to both PARP inhibitor and cisplatin as a result of a secondary BRCA2 mutation that converts the parental nonsense mutation, p.Y1655X, to a silent mutation p.Y1655Y. The same silent mutation was also found in the drug-resistant tumour sample from the same patient.

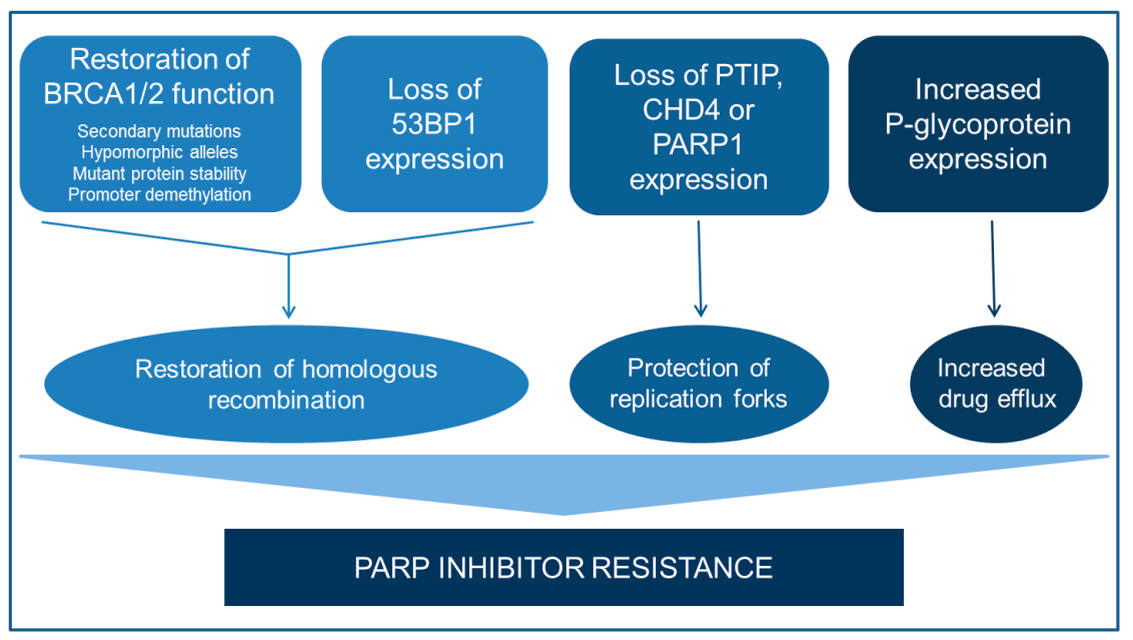

Figure 3

Mechanisms of PARP inhibitor resistance in BRCA1/2-associated cancers. Loss of PARP inhibitor resistance in BRCA1/2 mutated cancers can occur via (1) restoration of BRCA1/2 function and HR by secondary intragenic BRCA $1 / 2$ mutations, expression of hypomorphic BRCA1 alleles, stabilisation of mutant BRCA proteins and demethylation of the BRCA1 promoter; (2) restoration of HR as a result of relief from 53BP1-mediated block on end-resection (only in BRCA1 mutant tumour cells); (3) protection of replication forks, from MRE11-mediated degradation, due to loss of PTIP, CHD4 or PARP1 expression; and (4) increased efflux of PARP inhibitor from cancer cells as a result of increased P-glycoprotein expression. 
The restored BRCA2 proteins in CAPAN-1, PEO1 and $\mathrm{PEO} 4$ cells are functional as evidenced by the restoration of ionizing radiation-induced RAD51 foci formation, reduced DNA damage-induced chromosomal aberrations and cross-resistance to cisplatin. Non-BRCA2-restored clones of CAPAN-1 or PEO1 had neither secondary BRCA2 mutations nor restoration of damage-induced RAD51 foci formation. Importantly, depletion of BRCA2 by siRNA reversed the drug resistance in BRCA2-restored clones, and ectopic expression of the mutant BRCA2 proteins found in resistant clones led to drug resistance in BRCA2deficient backgrounds.

Although most pre-clinical studies identified mutations in BRCA2, and not BRCA1, that were associated with therapy resistance, several clinical studies have demonstrated that this is an effect that likely operates for both of the tumour suppressor genes. Norquist and coworkers evaluated PARP inhibitor response in cisplatin/ carboplatin-resistant ovarian tumours from patients with BRCA1 or BRCA2 mutations (Norquist et al. 2011). Of the three non-BRCA1/2-restored tumours, two showed complete response to PARP inhibitor and one showed a partial response. As expected, two of the three BRCA1/2restored tumours with secondary $B R C A 1 / 2$ mutations did not show response as the disease progressed presumably due to restored HR, whereas the third showed partial response (Norquist et al. 2011).

In another study, Barber and coworkers found evidence of secondary BRCA2 mutations in two PARP inhibitor-resistant tumours that were not present in matched treatment-naïve tumour samples from the same patients (Barber et al. 2013). A breast tumour from a male carrying the BRCA2c.9106C>T nonsense mutation had acquired a secondary mutation that changed the nonsense (p.Q2960X) to a missense (p.Q2960E) mutation. The second observation was a high-grade serous ovarian carcinoma from a patient carrying the BRCA2c.4705_4708delGAAA mutation, who was previously treated for breast cancer. In this case, the BRCA2 open reading frame was restored as a result of a larger deletion, BRCA2c.4697_4709delAAA TACTGAAAG, which encompassed the germ-line BRCA2 deletion mutation. Though not formally tested, both secondary BRCA2 mutations likely restore at least partially functional BRCA2 protein that cancels PARP inhibitorassociated synthetic lethality (Barber et al. 2013).

In a recent study, whole-genome sequencing and analysis of high-grade serous ovarian carcinomas revealed five individuals with platinum-resistant disease who had secondary BRCA1/2 mutations out of a total of ten patients analysed, who had germ-line BRCA1/2 mutations (Patch et al. 2015). One of the two patients, whose tumour was also cross-resistant to PARP inhibitor, had at least 12 distinct secondary deletion mutations in BRCA2 identified from multiple metastatic sites. The second patient had two distinct secondary BRCA1 mutations that changed the germ-line nonsense mutation to missense mutations in platinum-resistant cells.

A recent study by Jonkers and coworkers has also provided strong evidence for BRCA1 restoration as an important mechanism for PARP inhibitor and cisplatin resistance in BRCA1-deficient, triple-negative breast cancer (Ter Brugge et al. 2016). The analysis of patient-derived xenograft (PDX) models of triple-negative breast cancer included those derived from BRCA1-deficient tumours with $B R C A 1$ promoter hypermethylation and a frameshift mutation leading to a premature stop (BRCA1.c2210delC). In line with previous observations in BRCA1-mutated tumours, BRCA1 c2210delC therapy-resistant tumours had intragenic deletions that restore the BRCA1 open reading frame to reinstate BRCA1 protein expression and IR-induced RAD51 foci formation. Interestingly, demethylation of the $B R C A 1$ promoter was shown to be the major mechanism of resistance in therapy-resistant tumours derived from BRCA1 promoter hypermethylated tumours. BRCA1 gene fusions with other chromosome 17 genes also allowed the bypass of BRCA1 promoter hypermethylation to allow BRCA1 expression in a few drug-resistant tumours. Analysis of post-treatment tumours from individuals with BRCA1 promoter hypermethylation in pre-treatment samples showed a significant decrease in BRCA1 promoter methylation, which correlated with a similar increase in BRCA1 mRNA. Taken together, data from these studies provide strong evidence of BRCA1 restoration by multiple mechanisms, including BRCA1 promoter demethylation, as an important driver of PARP inhibitor and cisplatin resistance in BRCA1-deficient breast cancer.

Though clinical examples of secondary BRCA1/2 mutations in PARP inhibitor-resistant breast and other cancers remain few, more extensive data are available for secondary BRCA1/2 mutations in platinum-resistant cancers (Swisher et al. 2008, Dhillon et al. 2011, Norquist et al. 2011). Data from cell line models and the limited clinical samples suggest that BRCA1/2-restored, platinumresistant tumours have a high likelihood of being crossresistant to PARP inhibitor. Additionally, secondary BRCA1/2 mutations resulting in PARP inhibitor and cisplatin resistance are likely driven by the convergence of at least three different factors: increased mutation rate 
due to exposure to genotoxic agents, the lack of errorfree DNA repair and a selective advantage for BRCA1/2restored cells when patients are treated with PARP inhibitors or platinum salts.

Several examples of BRCA1/2 restoration by means other than secondary mutation also exist. For example, Johnson and coworkers showed that stabilisation of a normally undetectable mutant BRCA1 protein can lead to PARP inhibitor resistance in rucaparib-selected clones derived from the MDA-MB-436 breast cancer cell line, harbouring a $B R C A 1.5396+1 C>A$ splice donor site mutation (Johnson et al. 2013). Expression of an HSP90-stabilised, carboxy terminus-truncated BRCA1 protein results in restoration of damage-induced RAD51 foci formation and decreased PARP inhibitor-induced chromosomal aberrations. Reduced 53BP1 expression was also observed in rucaparib-resistant cells, which may allow increased BRCA1-independent CtIP-mediated resection, though 53BP1 loss alone was not sufficient to render cells resistant to the PARP inhibitor. The combination of mutant protein stabilisation and reduced 53BP1 expression was also observed in a clinical cisplatinresistant ovarian cancer sample though the response to PARP inhibitor is unknown.

In another study, Wang and coworkers demonstrated that breast cancer cell lines with mutations in the central large exon 11 of $B R C A 1$ expressing the $\Delta 11 \mathrm{q}$ splice variant show partial PARP inhibitor resistance and strong ionizing radiation-induced BRCA1 and RAD51 foci formation (Wang et al. 2016a). Depletion of the $\Delta 11 \mathrm{q}$ splice variant reduced foci formation and sensitized cells to PARP inhibitor and cisplatin. Moreover, 5-year overall survival in individuals with the exon 11 mutations was similar to those with wild-type BRCA1 and worse than those carrying mutations outside of exon 11.

Several groups have provided evidence for hypomorphic activity of two additional BRCA1 mutations that contribute to PARP inhibitor and cisplatin resistance (Drost et al. 2011, Drost et al. 2016, Powell 2016, Wang et al. 2016b). The BRCA1.C61G mutation in the RING domain abolishes BRCA1 ubiquitin ligase activity, while still promoting tumourigenesis. Importantly, mouse Brca1 . C61G cells are not sensitive to PARP inhibition suggesting the mutant protein retains at least partial function. Drost and coworkers also showed recently that a BRCA1 variant missing the RING domain ('RING-less' BRCA1) can be detected in cells from a mouse model carrying the Brca1.185STOP mutation and in the human breast cancer cell line SUM1315MO2 with the BRCA1.185delAG mutation (Drost et al. 2016). Importantly, expression of 'RING-less' BRCA1 renders cells partially resistant to PARP inhibitor and cisplatin, suggesting that its intact carboxy terminus provides partial function. Moreover, Wang and coworkers showed that PARP inhibitor and cisplatin-resistant clones of the SUM1315MO2 cell line had increased expression of the 'RING-less' BRCA1 variant that results from translation at an alternative start site (Wang et al. 2016b). Ectopic overexpression of this BRCA1 variant resulted in partial resistance to PARP inhibitor and cisplatin in vitro and in vivo. Interestingly, Drost and coworkers did not observe increased expression of the 'RING-less' BRCA1 consistently in cisplatin-resistant clones. The existence of partial function mutants warrants a better understanding of how specific mutations impact response to PARP inhibitor, cisplatin and other therapies and the clinical management of BRCA-deficient breast and other types of cancers.

\section{Loss of 53BP1 expression}

BRCA1 and 53BP1 play important roles in choice of DSB repair by HR or NHEJ: BRCA1 promotes HR, whereas 53BP1 tips the balance in favour of NHEJ. Several groups have shown that loss of the 53bp1 in a Brca1-null or Brca1Aexon11 mice rescues embryonic lethality observed in Brca1-deficient mice (Cao et al. 2009, Bouwman et al. 2010, Bunting et al. 2010). Brca1/53bp1-deficient cells and mice also have restored growth, decreased chromosomal aberrations, increased RAD51 foci formation and at least partially restored HR relative to Brca1-deficient mice. Importantly, the loss of 53bp1 in Brca1-deficient mice renders them resistant to PARP inhibitor. Additionally, a subset of olaparib-resistant Brca1/P glycoprotein-deficient murine tumours had lost 53bp1 expression, whereas several others had heterogeneous expression (Jaspers et al. 2013). Bouwman et al also found reduced 53BP1 expression in clinical BRCA1/2-associated and triplenegative breast cancers (Bouwman et al. 2010). Lower 53BP1 expression was correlated with lower metastasisfree survival, presumably due to reduced response to therapy. Together these data suggested that 53BP1 loss in a BRCA1-deficient background is a mechanism of PARP inhibitor resistance in mice and humans. The prevalence of 53BP1 loss in patients with BRCA1-associated and triple-negative breast cancer remains to be determined.

\section{Replication fork protection}

Studies investigating the mechanisms that mediate replication fork stability in the absence of $B R C A 1$ or

Published by Bioscientifica Ltd. 
$B R C A 2$ have led to a number of additional mechanisms of drug resistance to be proposed. As discussed earlier, replication forks in BRCA1/2 mutant cells are liable to degradation via MRE11 (Schlacher et al. 2011, 2012, Pathania et al. 2014). Chaudhuri and coworkers recently found that in Brca2 mutant cells, loss of PTIP improved cell viability, protected HU-stalled replication forks from MRE11-mediated degradation and decreased genetic instability (Chaudhuri et al. 2016). These effects were not caused by restoration of $\mathrm{HR}$, but are best explained by PTIP's role in localising MRE11 to replication forks. In the absence of PTIP, replication fork degradation via MRE11 was reduced, which in turn led to a reduction in replication fork degradation. Chaudhuri and coworkers also found that BRCA1/2-deficient cells with co-occurring PTIP defects also showed a reduced number of chromosomal abnormalities when exposed to either cisplatin or a PARP inhibitor, suggesting that these processes could influence BRCA1/2 mutant tumour cell response to therapy (Chaudhuri et al. 2016). In a series of Brca2-deficient, PARP inhibitor-resistant mouse tumours, RAD51 foci formation was not restored, but replication fork degradation after HU challenge was reduced, suggesting that HR restoration was not the cause of drug resistance in this case, but that restoration of fork stability could be (Chaudhuri et al. 2016). Taken together, these data provide a case for assessing biomarkers of replication fork stability in clinical trials involving BRCA1/2 mutant cancer patients.

\section{PARP inhibitor resistance due to increased efflux}

Increased efflux of PARP inhibitor from cancer cells also contributes to PARP inhibitor resistance in the BRCA1/2 mutation context. Rottenberg and coworkers showed that mammary tumours in Brca1/p53 double-mutant mice that are initially very responsive to olaparib eventually become resistant to the drug (Rottenberg et al. 2008). PARP inhibitor resistance in these tumours is mediated by increased expression of P-glycoprotein (Pgp) transporter genes $A b c b 1 a$ and $A b c b 1 b$ and can be reversed by inhibiting Pgp activity with tariquidar. Knockout of the Pgp $M d r 1 a / b$ gene in a Brca1 mutant background improved the response of mammary tumours to PARP inhibitor, though they eventually became resistant due to other mechanisms (Jaspers et al. 2013). Additionally, multidrug resistance, to drugs including olaparib, observed in a Brca2-mutated mouse model of mammary mesenchymal carcinosarcomas was, in part, due to increased Pgp expression (Jaspers et al. 2015). Though increased efflux via Pgp transporter upregulation leads to PARP inhibitor resistance in Brca1 and Brca2 mutant mouse models of breast cancer, it is yet to be reported in the clinic.

\section{BRCAness}

In addition to patients with germ-line $B R C A 1$ or $B R C A 2$ gene mutations ( $g B R C A)$, it seems very likely that significant numbers of cancer patients without gBRCA mutations have tumours that resemble, at the molecular and histological level, gBRCA mutant tumours, a phenomenon termed BRCAness (reviewed recently in (Lord \& Ashworth 2016)). In some cases, these shared molecular features might also drive the same defect in HR that could lead to sensitivity to BRCA synthetic lethal treatments such as PARP inhibitors.

BRCAness might be driven by several different mechanisms. With the onset of large-scale tumour sequencing, it is clear that in addition to germ-line $B R C A$ gene mutations, a significant proportion of non-familial cancers have somatic alterations in BRCA1, BRCA2 or the growing number of genes associated with HR. For example, triple-negative breast cancers, HGSOvCa, metastatic, castration-resistant prostate cancer and pancreatic ductal adenocarcinomas exhibit somatic alterations in BRCA1, $B R C A 2$ or BRCAness genes such as ATM, ATR, BAP1, $C D K 12, C H K 1, C H K 2$, the Fanconi anaemia proteins (FANCA, C, D2, E, F), PALB2, NBN, WRN, the RAD51 homologs RAD51B, C and D, MRE11A, BLM and BRIP1 (reviewed in (Lord \& Ashworth 2016)). Many of these genes have been shown in pre-clinical models to cause PARP inhibitor sensitivity when dysfunctional (McCabe et al. 2006, Blazek et al. 2011, Bajrami et al. 2014, Joshi et al. 2014), extending the causative link between HR dysfunction and sensitivity to these drugs.

There is also growing evidence for BRCAness in tumours that have a particular spectrum or pattern of mutations. One of the key observations made from the genomic profiling of tumours is the classification of tumours according to the type of mutations they possess, a mutational scar, rather than the specific genes that are mutated. In some instances, these mutational scars reflect the natural history of a tumour, and particularly the types of DNA damage and repair that have moulded the genome over successive cell cycles. For example, BRCA1 and $B R C A 2$ mutant tumours exhibit a mutational scar that appears to be caused by the elevated use of NHEJ, a DNA repair process that predominates in the absence of HR. For example, recent work from Nik-Zainal and coworkers, based on data from the whole-genome sequences of

Published by Bioscientifica Ltd. 
560 breast tumours, confirmed the presence of three distinct genomic rearrangement signatures associated with the loss of HR in tumours, each characterised by tandem DNA duplications or deletions. One of these signatures appears to be associated with loss of BRCA1 function, the second being associated with defective BRCA1 or BRCA2, with the aetiology of the third signature remaining largely unknown (Nik-Zainal et al. 2016). The discovery of these genomic signatures in part reflects observations made in genetically engineered mouse cell lines with either Brca1 or Brca2 mutations, where the use of non-conservative forms of DNA repair such as NHEJ results in an elevated frequency of DNA deletions flanked by short, tandem DNA repeats at the break points of the deletion (Moynahan et al. 2001b, Tutt et al. 2001, Xia et al. 2001). Mutational scars similar to those seen in $g B R C A$ mutant tumours are also seen in non-gBRCA mutant tumours, and even in those without a detectable germ-line or somatic alteration in an HR gene, suggesting that similar DNA repair defects might be operating in these tumours. Importantly, there is now a growing body of evidence, which suggests that the presence of such BRCAness mutational scars also correlates with clinical responses to HR-targeting agents such as platinum salts and PARP inhibitors (Birkbak et al. 2013), correlations which are driving the development of clinically applicable BRCAness mutational scar assays. Most of these assays use genome-wide DNA copy number profiling to estimate the extent of chromosomal rearrangements characteristic of an HR defect (Birkbak et al. 2013).

\section{Extending the utility of the synthetic lethal paradigm}

It seems reasonable to question whether synthetic lethality as a concept might have a wider applicability in the search for optimised treatments for breast cancer. The progress in the molecular profiling of breast tumours means that there is now a working list of driver gene defects in the disease that in principle could be targeted with a synthetic lethal approach. For example, many of the tumour suppressor gene defects that recurrently occur in breast cancer, such as TP53, PTEN and RB1, might be amenable to synthetic lethal approaches; already a number of candidate synthetic lethal targets for these genes have been identified (Edgar et al. 2005, Gordon \& Du 2011, Reaper et al. 2011, Mendes-Pereira et al. 2012, Emerling et al. 2013, Mereniuk et al. 2013, Morandell et al. 2013, Origanti et al. 2013). Many of the efforts to identify synthetic lethal interactions that are relevant to breast cancer have been driven by advances in functional genomic approaches such as RNA interference screening and more recently CRISPR-based screens (Gilbert et al. 2014, Wang et al. 2015, Morgens et al. 2016). The synthetic lethal approach might also be applied to target relatively common oncogene amplification events in breast cancer such as MYC amplification, which is present in over $22 \%$ of all breast tumours (Cerami et al. 2012, Gao et al. 2013, Ciriello et al. 2015). MYC encodes a transcription factor, which might be challenging to directly target with drug-like small molecules, and so using synthetic lethal strategies to targeting MYC amplification seems a reasonable approach. Already synthetic lethal interactions between MYC and the DR5 death receptor pathway (Wang et al. 2004) or inhibition of the splicesome in MYC-dependent breast tumours have been identified (Hsu et al. 2015). This latter observation might be explained by an increased dependency in MYC-amplified tumours on pre-mRNA processing (Hsu et al. 2015).

Although there are opportunities to more widely exploit the synthetic lethal concept in breast cancer, there are also clear challenges. For a synthetic lethal effect to be clinically actionable and to have significant utility, there are certain qualities the synthetic lethal relationship must exhibit, many of which are common to all ideal therapeutic approaches, synthetic lethal or not. Firstly, the therapeutic window between tumour and normal cell inhibition/toxicity achieved with the synthetic lethal target must be profound. Second, ideal synthetic lethal effects must be highly penetrant -i.e. the presence of the predictive biomarker (e.g. a mutation in a breast cancer driver gene) must be highly predictive of sensitivity to inhibition of the synthetic lethal target. If this is not the case, then a novel synthetic lethal treatment might only work in a minority of patients or a minority of tumour cell clones within an individual. Third, ideal synthetic lethal interactions must be relatively resilient to additional molecular changes that might reverse the synthetic lethal effect. This is critical if clinical synthetic lethal effects are to be effective in breast tumours, whose inherent molecular heterogeneity and ability to evolve and survive in the face of negative selective pressure is well documented (Alizadeh et al. 2015, Brooks et al. 2015). Despite advances in the ability to identify synthetic lethal effects in breast tumour cells, somewhat less attention is often given to whether these effects also fulfil these ideal criteria.

One concept that might gain further scrutiny in the future is the idea of exploiting combinations of different synthetic lethal effects in the same tumour, each of

Published by Bioscientifica Ltd. 
which focuses on a different breast cancer driver gene or phenotype. For example, in triple-negative breast cancers with germ-line or somatic BRCA gene mutations, TP53 mutations also co-occur. It seems reasonable to suggest that a drug combination strategy that involves a PARP inhibitor (to synthetically lethal target the $B R C A$ gene defect), used alongside a TP53 synthetic lethal therapy, might be more effective than PARP inhibitor monotherapy, which might be limited by the emergence of secondary mutant BRCA1/2 alleles. This idea of targeting multiple co-occurring driver mutations in the same tumour might be most effective when mutations that occur early on in the disease process, and so are more likely present in most subclones in a tumour, are selected.

\section{Conclusions and future prospects}

The cloning of BRCA1 and BRCA2 stimulated a large body of work, from many investigators, that ultimately resulted in the first clinically approved treatment for a genetically defined cancer syndrome. Although this work provides a very compelling narrative that illustrates the influence preclinical and clinical research can have, several important questions still remain. Some of these pertain directly to the use of PARP inhibitors, whereas others are also relevant to the treatment of cancer in general. For example, although olaparib has been approved for use as a maintenance therapy after platinum treatment in HGSOv cancer, a role for first-line PARP inhibitor treatment in BRCA1 or BRCA2 mutant patients, or those with BRCAness, remains to be established. There is also very little understanding about what might constitute the optimal drug combination strategies involving PARP inhibitors or how patients with PARP inhibitor resistance might best be treated. It seems reasonable to suggest that some of the answers to these questions will come from clinical studies but also will be informed by pre-clinical research and a continued focus on the molecular biology of the BRCA1 and BRCA2 genes. Beyond the BRCA/PARP inhibitor paradigm, the wider clinical applicability of the synthetic lethal concept is still not established, although it is hoped the continued preclinical research activity in this area will ultimately lead to further clinical trials drug approvals that deliver more effective treatments of cancer patients.

\section{Declaration of interest}

$C \mathrm{~J} \mathrm{~L}$ is a named inventor on patents describing the use of PARP inhibitors and stands to gain from their use as part of the ICR Rewards to Inventors Scheme.

\section{Funding}

This work was funded as follows: K K D is supported by the Thomsen Family Breast Cancer Research Fellowship; $T \mathrm{~T}$ is the recipient of support from the Howard Hughes Medical Institute, the Fanconi Anemia Research Fund and a V Foundation Grant in Translational Clinical Research; C J L is funded by Cancer Research UK, Breast Cancer Now and the Wellcome Trust.

\section{Acknowledgements}

The authors thank their funders (described above) for supporting their work in this area. C J L also acknowledges NHS funding to the NIHR Royal Marsden Hospital Biomedical Research Centre.

\section{References}

Alizadeh AA, Aranda V, Bardelli A, Blanpain C, Bock C, Borowski C, Caldas C, Califano A, Doherty M, Elsner M, et al. 2015 Toward understanding and exploiting tumor heterogeneity. Nature Medicine 21 846-853. (doi:10.1038/nm.3915)

Antoniou A, Pharoah PD, Narod S, Risch HA, Eyfjord JE, Hopper JL, Loman N, Olsson H, Johannsson O, Borg A, et al. 2003 Average risks of breast and ovarian cancer associated with BRCA1 or BRCA2 mutations detected in case series unselected for family history: a combined analysis of 22 studies. American Journal of Human Genetics 72 5. (doi:10.1086/375033)

Audeh MW, Carmichael J, Penson RT, Friedlander M, Powell B, BellMcGuinn KM, Scott C, Weitzel JN, Oaknin A, Loman N, et al. 2010 Oral poly(ADP-ribose) polymerase inhibitor olaparib in patients with BRCA1 or BRCA2 mutations and recurrent ovarian cancer: a proofof-concept trial. Lancet 376 245-251. (doi:10.1016/S01406736(10)60893-8)

Bajrami I, Frankum JR, Konde A, Miller RE, Rehman FL, Brough R, Campbell J, Sims D, Rafiq R, Hooper S, et al. 2014 Genome-wide profiling of genetic synthetic lethality identifies CDK12 as a novel determinant of PARP1/2 inhibitor sensitivity. Cancer Research $\mathbf{7 4}$ 287-297. (doi:10.1158/0008-5472.CAN-13-2541)

Balmana J, Domchek SM, Tutt A \& Garber JE 2011 Stumbling blocks on the path to personalized medicine in breast cancer: the case of PARP inhibitors for BRCA1/2-associated cancers. Cancer Discovery $129-34$. (doi:10.1158/2159-8274.CD-11-0048)

Barber LJ, Sandhu S, Chen L, Campbell J, Kozarewa I, Fenwick K, Assiotis I, Rodrigues DN, Reis Filho JS, Moreno V, et al. 2013 Secondary mutations in BRCA2 associated with clinical resistance to a PARP inhibitor. Journal of Pathology 229 422-429. (doi:10.1002/ path.4140)

Bartz SR, Zhang Z, Burchard J, Imakura M, Martin M, Palmieri A, Needham R, Guo J, Gordon M, Chung N, et al. 2006 Small interfering RNA screens reveal enhanced cisplatin cytotoxicity in tumor cells having both BRCA network and TP53 disruptions. Molecular and Cell Biology 26 9377-9386. (doi:10.1128/MCB.01229-06)

Birkbak NJ, Kochupurakkal B, Izarzugaza JM, Eklund AC, Li Y, Liu J, Szallasi Z, Matulonis UA, Richardson AL, Iglehart JD, et al. 2013 Tumor mutation burden forecasts outcome in ovarian cancer with BRCA1 or BRCA2 mutations. PLOS ONE 8 e80023. (doi:10.1371/ journal.pone.0080023)

Blazek D, Kohoutek J, Bartholomeeusen K, Johansen E, Hulinkova P, Luo Z, Cimermancic P, Ule J \& Peterlin BM 2011 The Cyclin K/Cdk12 complex maintains genomic stability via regulation of expression of DNA damage response genes. Genes \& Development $\mathbf{2 5}$ 2158-2172. (doi:10.1101/gad.16962311)

Bouwman P, Aly A, Escandell JM, Pieterse M, Bartkova J, van der Gulden H, Hiddingh S, Thanasoula M, Kulkarni A, Yang Q, et al.
(C) 2016 Society for Endocrinology Printed in Great Britain 
2010 53BP1 loss rescues BRCA1 deficiency and is associated with triple-negative and BRCA-mutated breast cancers. Nature Structural \& Molecular Biology 17 688-695. (doi:10.1038/nsmb.1831)

Boyd J, Sonoda Y, Federici MG, Bogomolniy F, Rhei E, Maresco DL, Saigo PE, Almadrones LA, Barakat RR, Brown CL, et al. 2000 Clinicopathologic features of BRCA-linked and sporadic ovarian cancer. JAMA 283 2260-2265. (doi:10.1001/jama.283.17.2260)

Breast Cancer Linkage Consortium 1999 Cancer risks in BRCA2 mutation carriers. Journal of National Cancer Institute 91 1310-1316. (doi:10.1093/jnci/91.15.1310)

Brooks MD, Burness ML \& Wicha MS 2015 Therapeutic implications of cellular heterogeneity and plasticity in breast cancer. Cell Stem Cell 17 260-271. (doi:10.1016/j.stem.2015.08.014)

Bryant HE, Schultz N, Thomas HD, Parker KM, Flower D, Lopez E, Kyle S, Meuth M, Curtin NJ \& Helleday T 2005 Specific killing of BRCA2-deficient tumours with inhibitors of poly(ADP-ribose) polymerase. Nature 434 913-917. (doi:10.1038/nature03443)

Brzovic PS, Rajagopal P, Hoyt DW, King MC \& Klevit RE 2001 Structure of a BRCA1-BARD1 heterodimeric RING-RING complex. Nature Structural Biology 8 833-837. (doi:10.1038/nsb1001-833)

Bunting SF, Callen E, Wong N, Chen HT, Polato F, Gunn A, Bothmer A, Feldhahn N, Fernandez-Capetillo O, Cao L, et al. 2010 53BP1 inhibits homologous recombination in Brca1-deficient cells by blocking resection of DNA breaks. Cell 141 243-254. (doi:10.1016/j. cell.2010.03.012)

Cao L, Xu X, Bunting SF, Liu J, Wang RH, Cao LL, Wu JJ, Peng TN, Chen J, Nussenzweig A, et al. 2009 A selective requirement for 53BP1 in the biological response to genomic instability induced by Brca1 deficiency. Molecular Cell 35 534-541. (doi:10.1016/j. molcel.2009.06.037)

Cass I, Baldwin RL, Varkey T, Moslehi R, Narod SA \& Karlan BY 2003 Improved survival in women with BRCA-associated ovarian carcinoma. Cancer 97 2187-2195. (doi:10.1002/cncr.11310)

Cerami E, Gao J, Dogrusoz U, Gross BE, Sumer SO, Aksoy BA, Jacobsen A, Byrne CJ, Heuer ML, Larsson E, et al. 2012 The cBio cancer genomics portal: an open platform for exploring multidimensional cancer genomics data. Cancer Discovery 2 401-404. (doi:10.1158/2159-8290.CD-12-0095)

Champoux JJ 2001 DNA topoisomerases: structure, function, and mechanism. Annual Review of Biochemistry 70 369-413. (doi:10.1146/ annurev.biochem.70.1.369)

Chaudhuri AR, Callen E, Ding X, Gogola E, Duarte AA, Lee JE, Wong N, Lafarga V, Calvo JA, Panzarino NJ, et al. 2016 Replication fork stability confers chemoresistance in BRCA-deficient cells. Nature $\mathbf{5 3 5}$ 382-387. (doi:10.1038/nature18325)

Chen L, Nievera CJ, Lee AY \& Wu X 2008 Cell cycle-dependent complex formation of BRCA1.CtIP.MRN is important for DNA double-strand break repair. Journal of Biological Chemistry 283 7713-7720. (doi:10.1074/jbc.M710245200)

Chetrit A, Hirsh-Yechezkel G, Ben-David Y, Lubin F, Friedman E \& Sadetzki S 2008 Effect of BRCA1/2 mutations on long-term survival of patients with invasive ovarian cancer: the national Israeli study of ovarian cancer. Journal of Clinical Oncology 26 20-25. (doi:10.1200/ JCO.2007.11.6905)

Ciriello G, Gatza ML, Beck AH, Wilkerson MD, Rhie SK, Pastore A, Zhang H, McLellan M, Yau C, Kandoth C, et al. 2015 Comprehensive molecular portraits of invasive lobular breast cancer. Cell 163 506-519. (doi:10.1016/j.cell.2015.09.033)

Collins N, McManus R, Wooster R, Mangion J, Seal S, Lakhani SR, Ormiston W, Daly PA, Ford D, Easton DF, et al. 1995 Consistent loss of the wild type allele in breast cancers from a family linked to the BRCA2 gene on chromosome 13q12-13. Oncogene 10 1673-1675.

Dhillon KK, Swisher EM \& Taniguchi T 2011 Secondary mutations of BRCA1/2 and drug resistance. Cancer Science 102 663-669. (doi:10.1111/j.1349-7006.2010.01840.x)
Domchek SM, Tang J, Stopfer J, Lilli DR, Hamel N, Tischkowitz M, Monteiro AN, Messick TE, Powers J, Yonker A, et al. 2013 Biallelic deleterious BRCA1 mutations in a woman with early-onset ovarian cancer. Cancer Discovery 3 399-405. (doi:10.1158/2159-8290.CD-120421)

Drost R, Bouwman P, Rottenberg S, Boon U, Schut E, Klarenbeek S, Klijn C, van der Heijden I, van der Gulden H, Wientjens E, et al. 2011 BRCA1 RING function is essential for tumor suppression but dispensable for therapy resistance. Cancer Cell 20 797-809. (doi:10.1016/j.ccr.2011.11.014)

Drost R, Dhillon KK, van der Gulden H, van der Heijden I, Brandsma I, Cruz C, Chondronasiou D, Castroviejo-Bermejo M, Boon U, Schut E, et al. 2016 BRCA1185delAG tumors may acquire therapy resistance through expression of RING-less BRCA1. Journal of Clinical Investigation 126 2903-2918. (doi:10.1172/JCI70196)

Edgar KA, Belvin M, Parks AL, Whittaker K, Mahoney MB, Nicoll M, Park CC, Winter CG, Chen F, Lickteig K, et al. 2005 Synthetic lethality of retinoblastoma mutant cells in the Drosophila eye by mutation of a novel peptidyl prolyl isomerase gene. Genetics $\mathbf{1 7 0}$ 161-171. (doi:10.1534/genetics.104.036343)

Edwards SM, Kote-Jarai Z, Meitz J, Hamoudi R, Hope Q, Osin P, Jackson R, Southgate C, Singh R, Falconer A, et al. 2003 Two percent of men with early-onset prostate cancer harbor germline mutations in the BRCA2 gene. American Journal of Human Genetics 72 1-12. (doi:10.1086/345310)

Edwards SL, Brough R, Lord CJ, Natrajan R, Vatcheva R, Levine DA, Boyd J, Reis-Filho JS \& Ashworth A 2008 Resistance to therapy caused by intragenic deletion in BRCA2. Nature 451 1111-1115. (doi:10.1038/nature06548)

Emerling BM, Hurov JB, Poulogiannis G, Tsukazawa KS, Choo-Wing R, Wulf GM, Bell EL, Shim HS, Lamia KA, Rameh LE, et al. 2013 Depletion of a putatively druggable class of phosphatidylinositol kinases inhibits growth of p53-null tumors. Cell 155 844-857. (doi:10.1016/j.cell.2013.09.057)

Evers B, Drost R, Schut E, de Bruin M, van der Burg E, Derksen PW, Holstege H, Liu X, van Drunen E, Beverloo HB, et al. 2008 Selective inhibition of BRCA2-deficient mammary tumor cell growth by AZD2281 and cisplatin. Clinical Cancer Research 14 3916-3925. (doi:10.1158/1078-0432.CCR-07-4953)

Farmer H, McCabe N, Lord CJ, Tutt AN, Johnson DA, Richardson TB, Santarosa M, Dillon KJ, Hickson I, Knights C, et al. 2005 Targeting the DNA repair defect in BRCA mutant cells as a therapeutic strategy. Nature 434 917-921. (doi:10.1038/nature03445)

Fedier A, Steiner RA, Schwarz VA, Lenherr L, Haller U \& Fink D 2003 The effect of loss of Brca1 on the sensitivity to anticancer agents in p53-deficient cells. International Journal of Oncology 22 1169-1173. (doi:10.3892/ijo.22.5.1169)

Fong PC, Boss DS, Yap TA, Tutt A, Wu P, Mergui-Roelvink M, Mortimer P, Swaisland H, Lau A, O'connor MJ, et al. 2009 Inhibition of poly(ADP-ribose) polymerase in tumors from BRCA mutation carriers. New England Journal of Medicine 361 123-134. (doi:10.1056/ NEJMoa0900212)

Fong PC, Yap TA, Boss DS, Carden CP, Mergui-Roelvink M, Gourley C, De Greve J, Lubinski J, Shanley S, Messiou C, et al. 2010 Poly(ADP)ribose polymerase inhibition: frequent durable responses in BRCA carrier ovarian cancer correlating with platinum-free interval. Journal of Clinical Oncology 28 2512-2519. (doi:10.1200/JCO.2009.26.9589)

Ford D, Easton DF, Stratton M, Narod S, Goldgar D, Devilee P, Bishop DT, Weber B, Lenoir G, Chang-Claude J, et al. 1998 Genetic heterogeneity and penetrance analysis of the BRCA1 and BRCA2 genes in breast cancer families. The Breast Cancer Linkage Consortium. American Journal of Human Genetics 62 676-689. (doi:10.1086/301749)

Foulkes WD, Stefansson IM, Chappuis PO, Begin LR, Goffin JR, Wong N, Trudel M \& Akslen LA 2003 Germline BRCA1 mutations and a basal http://erc.endocrinology-journals.org

DOI: $10.1530 /$ ERC-16-0228
(C) 2016 Society for Endocrinology Printed in Great Britain
Published by Bioscientifica Ltd 
epithelial phenotype in breast cancer. Journal of National Cancer Institute 95 1482-1485. (doi:10.1093/jnci/djg050)

Futreal PA, Liu Q, Shattuck-Eidens D, Cochran C, Harshman K, Tavtigian S, Bennett LM, Haugen-Strano A, Swensen J, Miki Y, et al. 1994 BRCA1 mutations in primary breast and ovarian carcinomas. Science 266 120-122. (doi:10.1126/science.7939630)

Gandhi V, Legha J, Chen F, Hertel LW \& Plunkett W 1996 Excision of $2^{\prime}, 2^{\prime}$-difluorodeoxycytidine (gemcitabine) monophosphate residues from DNA. Cancer Research 56 4453-4459.

Gao J, Aksoy BA, Dogrusoz U, Dresdner G, Gross B, Sumer SO, Sun Y, Jacobsen A, Sinha R, Larsson E, et al. 2013 Integrative analysis of complex cancer genomics and clinical profiles using the cBioPortal. Science Signaling 6 pl1. (doi:10.1126/scisignal.2004088)

Gelmon KA, Tischkowitz M, Mackay H, Swenerton K, Robidoux A, Tonkin K, Hirte H, Huntsman D, Clemons M, Gilks B, et al. 2011 Olaparib in patients with recurrent high-grade serous or poorly differentiated ovarian carcinoma or triple-negative breast cancer: a phase 2, multicentre, open-label, non-randomised study. Lancet Oncology 12 852-861. (doi:10.1016/S1470-2045(11)70214-5)

Gilbert LA, Horlbeck MA, Adamson B, Villalta JE, Chen Y, Whitehead EH, Guimaraes C, Panning B, Ploegh HL, Bassik MC, et al. 2014 Genome-scale CRISPR-mediated control of gene repression and activation. Cell 159 647-661. (doi:10.1016/j. cell.2014.09.029)

Gordon GM \& Du W 2011 Targeting Rb inactivation in cancers by synthetic lethality. American Journal of Cancer Research 1 773-786.

Gudmundsson J, Johannesdottir G, Bergthorsson JT, Arason A, Ingvarsson S, Egilsson V \& Barkardottir RB 1995 Different tumor types from BRCA2 carriers show wild-type chromosome deletions on 13q12-q13. Cancer Research 55 4830-4832.

Higuchi T, Flies DB, Marjon NA, Mantia-Smaldone G, Ronner L, Gimotty PA \& Adams SF 2015 CTLA-4 Blockade synergizes therapeutically with parp inhibition in BRCA1-deficient ovarian cancer. Cancer Immunology Research 3 1257-1268. (doi:10.1158/23266066.CIR-15-0044)

Hirschhorn R 2003 In vivo reversion to normal of inherited mutations in humans. Journal of Medical Genetics 40 721-728. (doi:10.1136/ jmg.40.10.721)

Hottiger MO, Hassa PO, Luscher B, Schuler H \& Koch-Nolte F 2010 Toward a unified nomenclature for mammalian ADPribosyltransferases. Trends in Biochemical Sciences 35 208-219. (doi:10.1016/j.tibs.2009.12.003)

Howlett NG, Taniguchi T, Olson S, Cox B, Waisfisz Q, De DieSmulders C, Persky N, Grompe M, Joenje H, Pals G, et al. 2002 Biallelic inactivation of BRCA2 in Fanconi anemia. Science 297 606-609. (doi:10.1126/science.1073834)

Hsu TY, Simon LM, Neill NJ, Marcotte R, Sayad A, Bland CS, Echeverria GV, Sun T, Kurley SJ, Tyagi S, et al. 2015 The spliceosome is a therapeutic vulnerability in MYC-driven cancer. Nature $\mathbf{5 2 5}$ 384-388. (doi:10.1038/nature14985)

Ikeda H, Matsushita M, Waisfisz Q, Kinoshita A, Oostra AB, Nieuwint AW, De Winter JP, Hoatlin ME, Kawai Y, Sasaki MS, et al. 2003 Genetic reversion in an acute myelogenous leukemia cell line from a Fanconi anemia patient with biallelic mutations in BRCA2. Cancer Research 63 2688-2694.

Jaspers JE, Kersbergen A, Boon U, Sol W, van Deemter L, Zander SA, Drost R, Wientjens E, Ji J, Aly A, et al. 2013 Loss of 53BP1 causes PARP inhibitor resistance in Brca1-mutated mouse mammary tumors. Cancer Discovery 3 68-81. (doi:10.1158/2159-8290.CD-120049)

Jaspers JE, Sol W, Kersbergen A, Schlicker A, Guyader C, Xu G, Wessels L, Borst P, Jonkers J \& Rottenberg S 2015 BRCA2-deficient sarcomatoid mammary tumors exhibit multidrug resistance. Cancer Research 75 732-741. (doi:10.1158/0008-5472.CAN-14-0839)

Johnson N, Johnson SF, Yao W, Li YC, Choi YE, Bernhardy AJ, Wang Y, Capelletti M, Sarosiek KA, Moreau LA, et al. 2013 Stabilization of mutant BRCA1 protein confers PARP inhibitor and platinum resistance. PNAS 110 17041-17046. (doi:10.1073/pnas.1305170110)

Jonsson G, Staaf J, Vallon-Christersson J, Ringner M, Holm K, Hegardt C, Gunnarsson H, Fagerholm R, Strand C, Agnarsson BA, et al. 2010 Genomic subtypes of breast cancer identified by array comparative genomic hybridization display distinct molecular and clinical characteristics. Breast Cancer Research 12 R42. (doi:10.1186/ bcr2596)

Joshi PM, Sutor SL, Huntoon CJ \& Karnitz LM 2014 Ovarian cancerassociated mutations disable catalytic activity of CDK12, a kinase that promotes homologous recombination repair and resistance to cisplatin and poly(ADP-ribose) polymerase inhibitors. Journal of Biological Chemistry 289 9247-9253. (doi:10.1074/jbc. M114.551143)

Kass EM \& Jasin M 2010 Collaboration and competition between DNA double-strand break repair pathways. FEBS Letters 584 3703-3708. (doi:10.1016/j.febslet.2010.07.057)

Kaufman B, Shapira-Frommer R, Schmutzler RK, Audeh MW, Friedlander M, Balmana J, Mitchell G, Fried G, Stemmer SM, Hubert A, et al. 2015 Olaparib monotherapy in patients with advanced cancer and a germline BRCA1/2 mutation. Journal of Clinical Oncology 33 244-250. (doi:10.1200/JCO.2014.56.2728)

Kilburn LS \& Group TNTTM 2008 'Triple negative' breast cancer: a new area for phase III breast cancer clinical trials. Clinical Oncology 20 35-39. (doi:10.1016/j.clon.2007.09.010)

Kim G, Ison G, McKee AE, Zhang H, Tang S, Gwise T, Sridhara R, Lee E, Tzou A, Philip R, et al. 2015 FDA approval summary: olaparib monotherapy in patients with deleterious germline BRCA-mutated advanced ovarian cancer treated with three or more lines of chemotherapy. Clinical Cancer Research 21 4257-4261. (doi:10.1158/1078-0432.CCR-15-0887)

King MC 2014 "The race" to clone BRCA1. Science 343 1462-1465. (doi:10.1126/science.1251900)

King MC, Marks JH \& Mandell JB 2003 Breast and ovarian cancer risks due to inherited mutations in BRCA1 and BRCA2. Science $\mathbf{3 0 2}$ 643-646. (doi:10.1126/science.1088759)

Ledermann J, Harter P, Gourley C, Friedlander M, Vergote I, Rustin G, Scott C, Meier W, Shapira-Frommer R, Safra T, et al. 2012 Olaparib maintenance therapy in platinum-sensitive relapsed ovarian cancer. New England Journal of Medicine 366 1382-1392. (doi:10.1056/ NEJMoa1105535)

Ledermann J, Harter P, Gourley C, Friedlander M, Vergote I, Rustin G, Scott CL, Meier W, Shapira-Frommer R, Safra T, et al. 2014 Olaparib maintenance therapy in patients with platinum-sensitive relapsed serous ovarian cancer: a preplanned retrospective analysis of outcomes by BRCA status in a randomised phase 2 trial. Lancet Oncology 15 852-861. (doi:10.1016/S1470-2045(14)70228-1)

Ledermann JA, Harter P, Gourley C, Friedlander M, Vergote I, Rustin GJS, Scott CL, Meier W, Shapira-Frommer R, Safra T, et al. 2016 (OS) in patients (pts) with platinum-sensitive relap(OS) in patients (pts) with platinum-sensitive relapsed serous ovarian cancer (PSR SOC) receiving olaparib maintenance monotherapy: an interim analysis. Journal of Clinical Oncology 34 (supplement; abstr 5501).

Lee J ZA, Lipkowitz S, Annunziata CM, Ho TW, Chiou VL, Minasian LM, Houston ND, Ekwede I \& Kohn EC 2016 Phase I study of the PD-L1 inhibitor, durvalumab (MEDI4736; D) in combination with a PARP inhibitor, olaparib (O) or a VEGFR inhibitor, cediranib (C) in women's cancers (NCT02484404). Journal of Clinical Oncology 34 (suppl; abstr 3015)

Livraghi L \& Garber JE 2015 PARP inhibitors in the management of breast cancer: current data and future prospects. BMC Medicine $\mathbf{1 3}$ 188. (doi:10.1186/s12916-015-0425-1)

Lord CJ \& Ashworth A 2012 The DNA damage response and cancer therapy. Nature 481 287-294. (doi:10.1038/nature10760)

Lord CJ \& Ashworth A 2016 BRCAness revisited. Nature Reviews Cancer 16 110-120. (doi:10.1038/nrc.2015.21) http://erc.endocrinology-journals.org

DOI: $10.1530 /$ ERC-16-0228
(C) 2016 Society for Endocrinology Printed in Great Britain 
Lord CJ, Tutt AN \& Ashworth A 2015 Synthetic lethality and cancer therapy: lessons learned from the development of PARP inhibitors. Annual Review of Medicine 66 455-470. (doi:10.1146/annurevmed-050913-022545)

Mateo J, Carreira S, Sandhu S, Miranda S, Mossop H, Perez-Lopez R, Nava Rodrigues D, Robinson D, Omlin A, Tunariu N, et al. 2015 DNA-repair defects and olaparib in metastatic prostate cancer. New England Journal of Medicine 373 1697-1708. (doi:10.1056/ NEJMoa1506859)

McCabe N, Turner NC, Lord CJ, Kluzek K, Bialkowska A, Swift S, Giavara S, O'Connor MJ, Tutt AN, Zdzienicka MZ, et al. 2006 Deficiency in the repair of DNA damage by homologous recombination and sensitivity to poly(ADP-ribose) polymerase inhibition. Cancer Research 66 8109-8115. (doi:10.1158/0008-5472. CAN-06-0140)

Mendes-Pereira AM, Lord CJ \& Ashworth A 2012 NLK is a novel therapeutic target for PTEN deficient tumour cells. PLOS ONE 7 e47249. (doi:10.1371/journal.pone.0047249)

Mereniuk TR, El Gendy MA, Mendes-Pereira AM, Lord CJ, Ghosh S, Foley E, Ashworth A \& Weinfeld M 2013 Synthetic lethal targeting of PTEN-deficient cancer cells using selective disruption of polynucleotide kinase/phosphatase. Molecular Cancer Therapy 12 2135-2144. (doi:10.1158/1535-7163.MCT-12-1093)

Meyer S, Tischkowitz M, Chandler K, Gillespie A, Birch JM \& Evans DG 2014 Fanconi anaemia, BRCA2 mutations and childhood cancer: a developmental perspective from clinical and epidemiological observations with implications for genetic counselling. Journal of Medical Genetics 51 71-75. (doi:10.1136/ jmedgenet-2013-101642)

Miki Y, Swensen J, Shattuck-Eidens D, Futreal PA, Harshman K, Tavtigian S, Liu Q, Cochran C, Bennett LM, Ding W, et al. 1994 A strong candidate for the breast and ovarian cancer susceptibility gene BRCA1. Science 266 66-71. (doi:10.1126/science.7545954)

Morandell S, Reinhardt HC, Cannell IG, Kim JS, Ruf DM, Mitra T, Couvillon AD, Jacks T \& Yaffe MB 2013 A reversible gene-targeting strategy identifies synthetic lethal interactions between MK2 and p53 in the DNA damage response in vivo. Cell Reports 5 868-877. (doi:10.1016/j.celrep.2013.10.025)

Morgens DW, Deans RM, Li A \& Bassik MC 2016 Systematic comparison of CRISPR/Cas9 and RNAi screens for essential genes. Nature Biotechnology 34 634-636. (doi:10.1038/nbt.3567)

Moynahan ME \& Jasin M 2010 Mitotic homologous recombination maintains genomic stability and suppresses tumorigenesis. Nature Reviews Molecular Cell Biology 11 196-207. (doi:10.1038/nrm2851)

Moynahan ME, Cui TY \& Jasin M 2001a Homology-directed DNA repair, mitomycin-c resistance, and chromosome stability is restored with correction of a Brca1 mutation. Cancer Research 61 4842-4850.

Moynahan ME, Pierce AJ \& Jasin M $2001 b$ BRCA2 is required for homology-directed repair of chromosomal breaks. Molecular Cell 7 263-272. (doi:10.1016/S1097-2765(01)00174-5)

Murai J, Huang SY, Das BB, Renaud A, Zhang Y, Doroshow JH, Ji J, Takeda S \& Pommier Y 2012 Trapping of PARP1 and PARP2 by clinical PARP inhibitors. Cancer Research 72 5588-5599. (doi:10.1158/0008-5472.CAN-12-2753)

Murai J, Huang SY, Renaud A, Zhang Y, Ji J, Takeda S, Morris J, Teicher B, Doroshow JH \& Pommier Y 2014 Stereospecific PARP trapping by BMN 673 and comparison with olaparib and rucaparib. Molecular Cancer Therapy 13 433-443. (doi:10.1158/1535-7163.MCT13-0803)

Narod SA 2010 BRCA mutations in the management of breast cancer: the state of the art. Natuer Reviews Clinical Oncology 7 702-707. (doi:10.1038/nrclinonc.2010.166)

Nik-Zainal S, Davies H, Staaf J, Ramakrishna M, Glodzik D, Zou X, Martincorena I, Alexandrov LB, Martin S, Wedge DC, et al. 2016 Landscape of somatic mutations in 560 breast cancer whole-genome sequences. Nature $\mathbf{5 3 4}$ 47-54. (doi:10.1038/nature17676)
Norquist B, Wurz KA, Pennil CC, Garcia R, Gross J, Sakai W, Karlan BY, Taniguchi T \& Swisher EM 2011 Secondary somatic mutations restoring BRCA1/2 predict chemotherapy resistance in hereditary ovarian carcinomas. Journal of Clinical Oncology 29 3008-3015. (doi:10.1200/JCO.2010.34.2980)

O'Connell BC, Adamson B, Lydeard JR, Sowa ME, Ciccia A, Bredemeyer AL, Schlabach M, Gygi SP, Elledge SJ \& Harper JW 2010 A genome-wide camptothecin sensitivity screen identifies a mammalian MMS22L-NFKBIL2 complex required for genomic stability. Molecular Cell 40 645-657. (doi:10.1016/j. molcel.2010.10.022)

Origanti S, Cai SR, Munir AZ, White LS \& Piwnica-Worms H 2013 Synthetic lethality of Chk1 inhibition combined with p53 and/or p21 loss during a DNA damage response in normal and tumor cells. Oncogene 32 577-588. (doi:10.1038/onc.2012.84)

Ozcelik H, Schmocker B, Di Nicola N, Shi XH, Langer B, Moore M, Taylor BR, Narod SA, Darlington G, Andrulis IL, et al. 1997 Germline BRCA2 6174delT mutations in Ashkenazi Jewish pancreatic cancer patients. Nature Genetics 16 17-18. (doi:10.1038/ng0597-17)

Patch AM, Christie EL, Etemadmoghadam D, Garsed DW, George J, Fereday S, Nones K, Cowin P, Alsop K, Bailey PJ, et al. 2015 Wholegenome characterization of chemoresistant ovarian cancer. Nature 521 489-494. (doi:10.1038/nature14410)

Pathania S, Bade S, Le Guillou M, Burke K, Reed R, Bowman-Colin C, Su Y, Ting DT, Polyak K, Richardson AL, et al. 2014 BRCA1 haploinsufficiency for replication stress suppression in primary cells. Nature Communications 5 5496. (doi:10.1038/ncomms6496)

Powell SN 2016 BRCA1 loses the ring but lords over resistance. Journal of Clinical Investigation 126 2802-2804. (doi:10.1172/JCI89209)

Rahden-Staron I, Szumilo M, Grosicka E, Kraakman van der Zwet M \& Zdzienicka MZ 2003 Defective Brca2 influences topoisomerase I activity in mammalian cells. Acta Biochimica Polonica 50 139-144.

Reaper PM, Griffiths MR, Long JM, Charrier JD, Maccormick S, Charlton PA, Golec JM \& Pollard JR 2011 Selective killing of ATM- or p53-deficient cancer cells through inhibition of ATR. Nature Chemical Biology 7 428-430. (doi:10.1038/nchembio.573)

Rottenberg S, Jaspers JE, Kersbergen A, van der Burg E, Nygren AO, Zander SA, Derksen PW, de Bruin M, Zevenhoven J, Lau A, et al. 2008 High sensitivity of BRCA1-deficient mammary tumors to the PARP inhibitor AZD2281 alone and in combination with platinum drugs. PNAS 105 17079-17084. (doi:10.1073/pnas.0806092105)

Sakai W, Swisher EM, Jacquemont C, Chandramohan KV, Couch FJ, Langdon SP, Wurz K, Higgins J, Villegas E \& Taniguchi T 2009 Functional restoration of BRCA2 protein by secondary BRCA2 mutations in BRCA2-mutated ovarian carcinoma. Cancer Research 69 6381-6386. (doi:10.1158/0008-5472.CAN-09-1178)

Sakai W, Swisher EM, Karlan BY, Agarwal MK, Higgins J, Friedman C, Villegas E, Jacquemont C, Farrugia DJ, Couch FJ, et al. 2008 Secondary mutations as a mechanism of cisplatin resistance in BRCA2-mutated cancers. Nature 451 1116-1120. (doi:10.1038/ nature06633)

Sartori AA, Lukas C, Coates J, Mistrik M, Fu S, Bartek J, Baer R, Lukas J \& Jackson SP 2007 Human CtIP promotes DNA end resection. Nature 450 509-514. (doi:10.1038/nature06337)

Sawyer SL, Tian L, Kahkonen M, Schwartzentruber J, Kircher M, University of Washington Centre for Mendelian Genomics, FORGE Canada Consortium, Majewski J, Dyment DA, Innes AM, et al. 2015 Biallelic mutations in BRCA1 cause a new Fanconi anemia subtype. Cancer Discovery 5 135-142. (doi:10.1158/2159-8290.CD-14-1156)

Schlacher K, Christ N, Siaud N, Egashira A, Wu H \& Jasin M 2011 Double-strand break repair-independent role for BRCA2 in blocking stalled replication fork degradation by MRE11. Cell 145 529-542. (doi:10.1016/j.cell.2011.03.041)

Schlacher K, Wu H \& Jasin M 2012 A distinct replication fork protection pathway connects Fanconi anemia tumor suppressors to RAD51BRCA1/2. Cancer Cell 22 106-116. (doi:10.1016/j.ccr.2012.05.015) 
Sharan SK, Morimatsu M, Albrecht U, Lim DS, Regel E, Dinh C, Sands A, Eichele G, Hasty P \& Bradley A 1997 Embryonic lethality and radiation hypersensitivity mediated by Rad51 in mice lacking Brca2 Nature 386 804-810. (doi:10.1038/386804a0)

Sikov WM 2015 Assessing the role of platinum agents in aggressive breast cancers. Current Oncology Reports 17 3. (doi:10.1007/s11912014-0428-7)

Silver DP, Richardson AL, Eklund AC, Wang ZC, Szallasi Z, Li Q, Juul N, Leong CO, Calogrias D, Buraimoh A, et al. 2010 Efficacy of neoadjuvant Cisplatin in triple-negative breast cancer. Journal of Clinical Oncology 28 1145-1153. (doi:10.1200/JCO.2009.22.4725)

Strickland KC, Howitt BE, Shukla SA, Rodig S, Ritterhouse LL, Liu JF, Garber JE, Chowdhury D, Wu CJ, D'Andrea AD, et al. 2016 Association and prognostic significance of BRCA1/2-mutation status with neoantigen load, number of tumor-infiltrating lymphocytes and expression of PD-1/PD-L1 in high grade serous ovarian cancer. Oncotarget 7 13587-13598. (doi:10.18632/oncotarget.7277)

Swisher EM, Sakai W, Karlan BY, Wurz K, Urban N \& Taniguchi T 2008 Secondary BRCA1 mutations in BRCA1-mutated ovarian carcinomas with platinum resistance. Cancer Research 68 2581-2586. (doi:10.1158/0008-5472.CAN-08-0088)

Sy SM, Huen MS \& Chen J 2009 PALB2 is an integral component of the BRCA complex required for homologous recombination repair. PNAS 106 7155-7160. (doi:10.1073/pnas.0811159106)

Tan DS, Rothermundt C, Thomas K, Bancroft E, Eeles R, Shanley S, Ardern-Jones A, Norman A, Kaye SB \& Gore ME 2008 "BRCAness" syndrome in ovarian cancer: a case-control study describing the clinical features and outcome of patients with epithelial ovarian cancer associated with BRCA1 and BRCA2 mutations. Journal of Clinical Oncology 26 5530-5536. (doi:10.1200/JCO.2008.16.1703)

Tavtigian SV, Simard J, Rommens J, Couch F, Shattuck-Eidens D, Neuhausen S, Merajver S, Thorlacius S, Offit K, Stoppa-Lyonnet D, et al. 1996 The complete BRCA2 gene and mutations in chromosome 13q-linked kindreds. Nature Genetics 12 333-337. (doi:10.1038/ ng0396-333)

Ter Brugge P, Kristel P, van der Burg E, Boon U, de Maaker M, Lips E, Mulder L, de Ruiter J, Moutinho C, Gevensleben H, et al. 2016 Mechanisms of therapy resistance in patient-derived xenograft models of BRCA1-deficient breast cancer. Journal of National Cancer Institute 108 djw148. (doi:10.1093/jnci/djw148)

Tischkowitz M \& Xia B 2010 PALB2/FANCN: recombining cancer and Fanconi anemia. Cancer Research 70 7353-7359. (doi:10.1158/00085472.CAN-10-1012)

Turner N, Tutt A \& Ashworth A 2004 Hallmarks of 'BRCAness' in sporadic cancers. Nature Reviews Cancer 4 814-819. (doi:10.1038/nrc1457)

Tutt A, Bertwistle D, Valentine J, Gabriel A, Swift S, Ross G, Griffin C, Thacker J \& Ashworth A 2001 Mutation in Brca2 stimulates errorprone homology-directed repair of DNA double-strand breaks occurring between repeated sequences. EMBO Journal 20 4704-4716. (doi:10.1093/emboj/20.17.4704)

Tutt A, Robson M, Garber JE, Domchek SM, Audeh MW, Weitzel JN, Friedlander M, Arun B, Loman N, Schmutzler RK, et al. 2010 Oral poly(ADP-ribose) polymerase inhibitor olaparib in patients with BRCA1 or BRCA2 mutations and advanced breast cancer: a proof-of-concept trial. Lancet 376 235-244. (doi:10.1016/S01406736(10)60892-6)

van Asperen CJ, Brohet RM, Meijers-Heijboer EJ, Hoogerbrugge N, Verhoef S, Vasen HF, Ausems MG, Menko FH, Gomez Garcia EB, Klijn JG, et al. 2005 Cancer risks in BRCA2 families: estimates for sites other than breast and ovary. Journal of Medical Genetics 42 711-719. (doi:10.1136/jmg.2004.028829)
Vencken PM, Kriege M, Hoogwerf D, Beugelink S, van der Burg ME, Hooning MJ, Berns EM, Jager A, Collee M, Burger CW, et al. 2011 Chemosensitivity and outcome of BRCA1- and BRCA2-associated ovarian cancer patients after first-line chemotherapy compared with sporadic ovarian cancer patients. Annals of Oncology 22 1346-1352. (doi:10.1093/annonc/mdq628)

Waddell N, Arnold J, Cocciardi S, da Silva L, Marsh A, Riley J, Johnstone CN, Orloff M, Assie G, Eng C, et al. 2010 Subtypes of familial breast tumours revealed by expression and copy number profiling. Breast Cancer Research and Treatment 123 661-677. (doi:10.1007/s10549-009-0653-1)

Wang T, Birsoy K, Hughes NW, Krupczak KM, Post Y, Wei JJ, Lander ES \& Sabatini DM 2015 Identification and characterization of essential genes in the human genome. Science 350 1096-1101. (doi:10.1126/ science.aac7041)

Wang Y, Engels IH, Knee DA, Nasoff M, Deveraux QL \& Quon KC 2004 Synthetic lethal targeting of MYC by activation of the DR5 death receptor pathway. Cancer Cell 5 501-512. (doi:10.1016/S15356108(04)00113-8)

Wang Y, Bernhardy AJ, Cruz C, Krais JJ, Nacson J, Nicolas E, Peri S, van der Gulden H, van der Heijden I, O'Brien SW, et al. 2016a The BRCA1-Delta11q alternative splice isoform bypasses germline mutations and promotes therapeutic resistance to PARP inhibition and cisplatin. Cancer Research 76 2778-2790. (doi:10.1158/00085472.CAN-16-0186)

Wang Y, Krais JJ, Bernhardy AJ, Nicolas E, Cai KQ, Harrell MI, Kim HH, George E, Swisher EM, Simpkins F, et al. 2016b RING domaindeficient BRCA1 promotes PARP inhibitor and platinum resistance. Journal of Clinical Investigation 126 3145-3157. (doi:10.1172/ JCI87033)

Wiegant WW, Overmeer RM, Godthelp BC, van Buul PP \& Zdzienicka MZ 2006 Chinese hamster cell mutant, V-C8, a model for analysis of Brca2 function. Mutation Research 600 79-88. (doi:10.1016/j.mrfmmm.2006.03.001)

Wong AK, Pero R, Ormonde PA, Tavtigian SV \& Bartel PL 1997 RAD51 interacts with the evolutionarily conserved BRC motifs in the human breast cancer susceptibility gene brca2. Journal of Biological Chemical 272 31941-31944. (doi:10.1074/jbc.272.51.31941)

Wong AK, Ormonde PA, Pero R, Chen Y, Lian L, Salada G, Berry S, Lawrence Q, Dayananth P, Ha P, et al. 1998 Characterization of a carboxy-terminal BRCA1 interacting protein. Oncogene 17 2279-2285. (doi:10.1038/sj.onc.1202150)

Wooster R, Bignell G, Lancaster J, Swift S, Seal S, Mangion J, Collins N, Gregory S, Gumbs C \& Micklem G 1995 Identification of the breast cancer susceptibility gene BRCA2. Nature 378 789-792. (doi:10.1038/378789a0)

Wu LC, Wang ZW, Tsan JT, Spillman MA, Phung A, Xu XL, Yang MC, Hwang LY, Bowcock AM \& Baer R 1996 Identification of a RING protein that can interact in vivo with the BRCA1 gene product. Nature Genetics 14 430-440. (doi:10.1038/ng1296-430)

Xia F, Taghian DG, DeFrank JS, Zeng ZC, Willers H, Iliakis G \& Powell SN 2001 Deficiency of human BRCA2 leads to impaired homologous recombination but maintains normal nonhomologous end joining. PNAS 98 8644-8649. (doi:10.1073/ pnas.151253498)

Xia B, Sheng Q, Nakanishi K, Ohashi A, Wu J, Christ N, Liu X, Jasin M, Couch FJ \& Livingston DM 2006 Control of BRCA2 cellular and clinical functions by a nuclear partner, PALB2. Molecular Cell 22 719-729. (doi:10.1016/j.molcel.2006.05.022)

Yang H, Jeffrey PD, Miller J, Kinnucan E, Sun Y, Thoma NH, Zheng N, Chen PL, Lee WH \& Pavletich NP 2002 BRCA2 function in DNA
๑ 2016 Society for Endocrinology Printed in Great Britain
Published by Bioscientifica Ltd. 
binding and recombination from a BRCA2-DSS1-ssDNA structure. Science 297 1837-1848. (doi:10.1126/science.297.5588.1837)

Yu X \& Baer R 2000 Nuclear localization and cell cycle-specific expression of CtIP, a protein that associates with the BRCA1 tumor suppressor. Journal of Biological Chemistry 275 18541-18549. (doi:10.1074/jbc.M909494199)

Yu X, Wu LC, Bowcock AM, Aronheim A \& Baer R 1998 The C-terminal (BRCT) domains of BRCA1 interact in vivo with CtIP, a protein implicated in the CtBP pathway of transcriptional repression. Journal of Biological Chemistry 273 25388-25392. (doi:10.1074/ jbc.273.39.25388)

Zhang F, Fan Q, Ren K \& Andreassen PR 2009a PALB2 functionally connects the breast cancer susceptibility proteins BRCA1 and BRCA2. Molecular Cancer Research 7 1110-1118. (doi:10.1158/1541-7786. MCR-09-0123)

Zhang F, Ma J, Wu J, Ye L, Cai H, Xia B \& Yu X 2009b PALB2 links BRCA1 and BRCA2 in the DNA-damage response. Current Biology 19 524-529. (doi:10.1016/j.cub.2009.02.018)

Received in final form 12 August 2016

Accepted 15 August 2016

Accepted Preprint 15 August 2016
Published by Bioscientifica Ltd. 